\title{
Pandemi COVID-19: Analisis Tantangan Kebijakan Ekonomi di Indonesia
}

\author{
"Covid-19 Pandemic: Analysis of Economic Policy Challenges in \\ Indonesia"
}

Oleh:

\author{
Johni Harius Putranto1), Totok Subagyo2), Sri Lestari ${ }^{3)}$ \\ STIE Mahardhika Surabaya1,2,3) \\ johni.putranto@stiemahardhika.ac.idi1); gioksubagyo@gmail.com²); sri.lestari@stiemahardhika.ac.id3)
}

Submit: 23 Jun $2021 \quad$ Review: 25 Jun $2021 \quad$ Accept: 29 Jun $2021 \quad$ Publish: 01 Jul 2021

\begin{abstract}
ABSTRAK
Sebagai negara dengan penduduk paling besar nomor 4 di dunia, Indonesia merupakan negara dengan dampak wabah COVID-19 paling parah di Asia Tenggara. Tujuan artikel ini adalah untuk melihat tantangan ekonomi yang dihadapi Indonesia selama pandemi. Data informasi kualitatif dari berbagai sumber telah digunakan. Analisis menunjukkan bahwa rumah sakit terbatas dengan perlengkapan yang kesehatan, kurangnya fasilitas kamar isolasi, kurangnya kesadaran, pengetahuan yang tidak tepat, sikap penerapan dalam kepatuhan terhadap peraturan, pekerjaan yang beresiko serta faktor-faktor yang dominan dalam penyebaran COVID-19. Tindakan penegakan pembatasan sosial yang ketat dan memastikan kepatuhan masyarakat terhadap aturan dapat membantu mengurangi penyebaran virus. Efek berkelanjutan ini menjadi tantangan besar pemerintah untuk memulihkan perekonomian dengan beberapa kebijakannya.
\end{abstract}

Kata kunci: Covid-19; Tantangan Ekonomi ; Analisa Kebijakan

\begin{abstract}
As the country with the 4th largest population in the world Indonesia is the country with the most severe impact of the COVID-19 outbreak in Southeast Asia. The purpose of this article is to look at the economic challenges facing Indonesia during the pandemic. Qualitative information data from various sources have been used. The analysis shows that hospitals are limited by health equipment, lack of isolation room facilities, lack of awareness, inappropriate knowledge, attitude in implementing compliance with regulations, risky work and the dominant factors in the spread of COVID-19. Strict social distancing enforcement measures and ensuring people's compliance with the rules can help reduce the spread of the virus. This continuous effect is a big challenge for the government to restore the economy with several policies.
\end{abstract}

Keywords: Covid 19; Economic Challenge; Policy Analisis 


\section{PENDAHULUAN}

Pandemi Flu 2009 yang terkenal dengan istilah Flu Babi menyerang Amerika Serikat dengan virus baru bernama H1N1. Sebelumnya ada pandemi Flu 1968 yang disebut sebagai Flu Hong Kong dengan virusnya bernama influenza A (H3N2). Pandemi terakhir adalah Corona Virus Disease 2019 (Covid-19) yang disebut bencana kemanusiaan terbesar dalam kurun waktu satu abad ini.

Wabah Cofid-19 pertama terjadi di Wuhan provinsi Hubei di Cina. Wabah ini memiliki tingkat mutasi dan penularan tinggi yang mampu menginfeksi manusia dengan sangat cepat. Sekitar 219 negara terkena virus mematikan ini yang mengakibatkan peningkatan jumlah kasus. Atas dasar itu, Organisasi Kesehatan Dunia (WHO) menetapkan Covid-19 sebagai pandemi karena penyebarannya yang signifikan ke seluruh dunia (WHO | World Health Organization, n.d.). Berdasarkan wilayahnya, dari data worldmeter info, Amerika dan Eropa dilaporkan memiliki jumlah kasus Covid-19 tertinggi 49.416.356 dan 32.326.901 kasus (Worldometer, n.d.)

Hingga 14 Februari 2021, ada lima negara dengan jumlah tertinggi kasus Covid-19 yang dikonfirmasi di seluruh dunia. Mereka adalah Amerika Serikat $(28,317,703)$, Brasil (9.866.710), India $(10,925,710)$, Rusia $(4,086,090)$ dan Britania Raya $(4,047,843)$. Sementara di Asia Tenggara, Indonesia memiliki jumlah kasus tertinggi hingga 1,223,930. Sejauh ini, jumlah total kematian di Indonesia mencapai 33.367 sedangkan total pemulihan mencapai 1.032 .065 (Worldometer, n.d.)

Indonesia sebagai negara berkembang di Asia Tenggara yang berpenduduk padat total populasi 269603,4 (Badan Pusat
Statistik, n.d.) menghadapi bencana karena munculnya penyebaran virus ini. Covid-19 pertama kali diidentifikasi di Indonesia pada 2 Maret 2020 dari ibu dan anak asal Depok Jawa Barat (Kasus Covid-19| Indonesia.Go.Id, n.d.)

Kepadatan penduduk yang tinggi membuat Indonesia lebih rentan terhadap penyebaran virus dibandingkan dengan negara-negara yang tidak memiliki tingkat kepadatan penduduk yang tinggi. Akibatnya, tantangan besar bagi Indonesia adalah membatasi kasus-kasus baru serta meminimalkan angka kematian.

Munculnya Pandemi Covid 19 menimbulkan goncangan ekonomi yang memerlukan penyesuaian dari para pelaku ekonomi dan juga pembuat kebijakan ekonomi. Hal ini dimaksudkan agar diperoleh kesimbangan ekonomi yang baru sesuai degan perilaku masyarakat yang baru (Taufik \& Ayuningtyas, 2020).

Beberapa kebijakan diterapkan oleh pemerintah untuk dapat tetap menghadapi resiko kesehatan pandemi dan mencapai pertumbuhan ekonomi yang positif. Kebijakan tersebut diantaranya adalah dukungan dan insentif kesehatan, dan tentu juga munculnya aturan prokes serta Pembatasan sosial berskala besar.

Pembatasan sosial berskala besar berkontribusi besar terhadap aktivitas dan pemulihan ekonomi, meningkatkan perlindungan sosial masyarakat melalui program keluarga harapan dan peningkatan anggaran kartu prakerja. Hal ini dimaksudkan untuk menjaga daya beli masyarakat agar aktivitas konsumsi dan produksi bersirkulasi meningkatkan output nasional. Beban biaya konsumsi masyarakat menjadi perhatian melalui kebijakan insentif tarif listrik, relaksasi kredit untuk memperpanjang nafas perekonomian yang terdampak besar. 
Beberapa kebijakan memang mampu meningkatkan geliat ekonomi di satu sisi, dan membutuhkan usaha ekstra besar untuk memulihkan disisi lain. Meskipun ada beberapa sektor ekonomi yang harus dan terpaksa bersifat menunggu pulihnya pandemic. Namun nampaknya masyarakat, pelaku maupun pembuatan kebijakan ekonomi harus bersahabat, sehingga muncul istilah kebiasaan baru atau new normal.

Artikel yang disamapikan ini untuk menganalisis tantangan ekonomi yang dihadapi negara dalam menangani krisis yang diakibatkan pandemi Covid-19. Artikel ini juga membahas masalah kepatuhan terhadap aturan dan praktik yang perlu diikuti oleh masyarakat agar mampu mengurangi penyebaran virus.

\section{METODE PENELITIAN}

Penelitian dilakukan di awal tahun 2021, dengan manggunakan data yang diperoleh selama pandemic Covid 19. Metodologi penelitian kualitatif digunakan dalam penelitian ini. Penelitian ini menggunaakan data dari sumber sekunder, informasi dari artikel surat kabar, situs web WHO, Worldometer, dan penelitian terkait. Selanjutnya dilakukan studi literature dan pengamatan pribadi tentang perilaku masyarakat terkait kebijakan ekonomi selama pandemic Covid 19 untuk memperoleh informasi kualitatif berbagai sumber.

\section{HASIL PENELITIAN DAN PEMBAHASAN}

\section{Analisis kondisi perekonomian}

Penutupan layanan publik dan pembatasan sosial berskala besar (PSBB) mengakibatkan krisis ekonomi bersamaan dengan krisis kesehatan. Sebagian besar tenaga kerja produktif diberhentikan dari pekerjaannya, dirumahkan untuk waktu tertentu, bahkan dilakukan Pemutusan Hubungan Kerja (PHK). Beberapa perusahaan yang bertahan melakukan langkah-langkah efisiensi. Namun tidak sedikit yang terpaksa gulung tikar. Kebijakan ini menciptakan dilema antara menyelamatkan nyawa dan mata pencaharian.

Indonesia yang jumlah penduduknya didominasi usia produktif, memiliki jumlah angkatan kerja sebanyak 138,22 juta orang. Data yang dirilis pada Agustus 2020, menunjukkan Tingkat Partisipasi Angkatan Kerja (TPAK) naik sebesar 0,24 persen poin (Statistik, 2020)

Satu tahun terakhir ini persentase pekerja yang menganggur dan bekerja paruh waktu naik $3.77 \%$ dan $3.42 \%$. Sementara sebanyak 29.12 juta (14.28\%) pekerja usia produktif terdampak Covid19. Mereka terbagi dari pengangguran karena Covid-19 sebanyak 2,56 juta orang, usia produktif Bukan Angkatan Kerja (BAK) sebanyak 0,76 juta orang, tidak bekerja karena Covid-19 sebesar 1,77 juta orang dan masyarakat yang mengalami pengurangan jam kerja karena Covid-19 mencapai 24,03 juta orang (Badan Pusat Statistik, 2020)

Status karantina wilayah atau lockdown di Indonesia menyebabkan menurunnya GDP sampai 4,5\%. Lebih jauh lagi, pasar finansial menurun drastis. Ekonomi Indonesia diperkirakan terkontraksi pada kuartal II dan kuartal III karena krisis global dan dampak pandemi kepada sektor-sektor ekonomi. Ekonomi Indonesia diperkirakan mengalami perbaikan pada kuartal IV dan membaik di tahun 2021 (Ismal, 2020)

Cadangan devisa masih tercatat USD 121 miliar (akhir maret 2020) dan sedikit mengalami penurunan dari USD 130,4 miliar (Februari 2020). Dituliskan pula bahwa pada pertengahan April 2020, kurs 
rupiah menguat 4,35\% sampai Rp. 15.000 . Inflasi dari bulan ke bulan (mtm) tercatat 0,10\% dan 2,96\% (yoy). Hal ini dikarenakan oleh penurunan permintaan dan terbatasnya pasokan barang.

Mewabahnya virus Covid-19 yang membuat beberapa negara termasuk Indonesia mengalami krisis ekonomi ditanggapi pemerintah dengan mulai mengambil langkah pemulihan ekonomi untuk menjaga perekonomian Indonesia tetap stabil. Sehingga ini bisa menjadi peluang sekaligus tantangan bagi pelaku ekonomi (Sumarni, 2020). Pemerintah membuat kebijakan moneter dan sinergi kebijakan ekonomi dengan penguatan paradigma kebijakan reformasi peran dan kebijakan bank sentral sejak pandemi covid-19. Selain melakukan kebijakan moneter untuk menstabilkan harga dan nilai tukar uang, pemerintah memberikan mandat tambahan kepada bank sentral dalam stabilitas sistim keuangan, makropudensial dan penguatan aliran modal asing (Ismal, 2020)

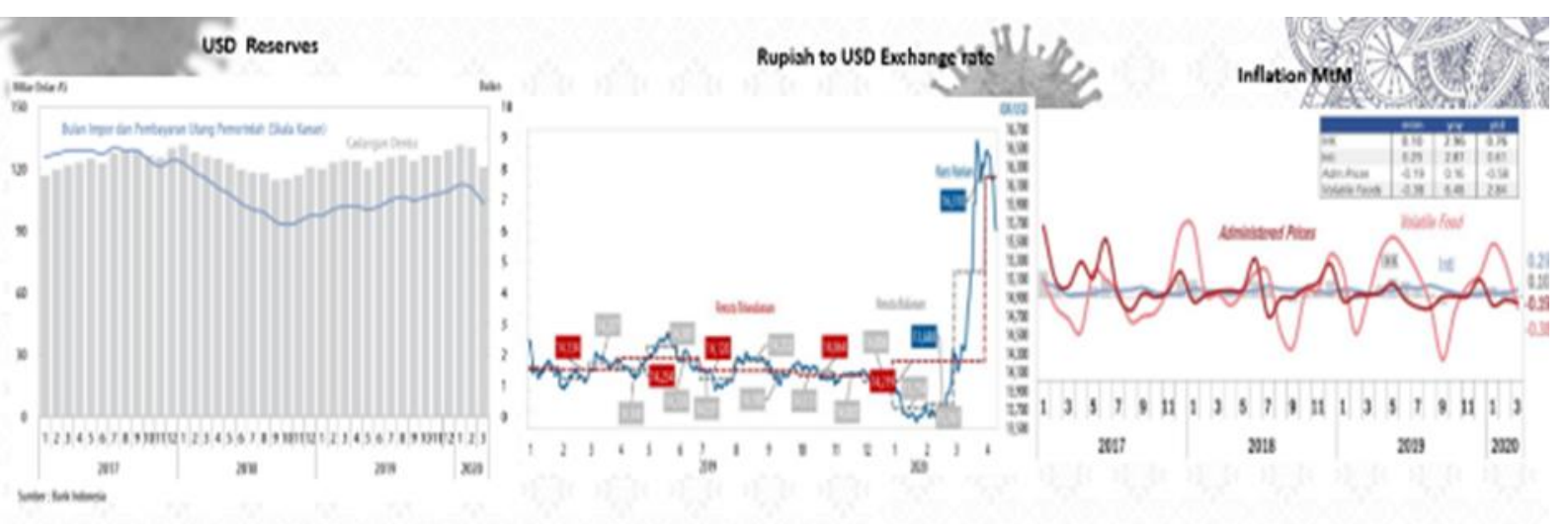

Gambar 1: Indikator Makroekonomi Indonesia

Pemulihan ekonomi dimulai pada pertengahan Februari-April 2020 dimana pemerintah menurunkan suku bunga dari 25 basis poin (bps) menjadi $4,50 \%-4,75 \%$. Sementara untuk stabilitas nilai tukar rupiah, pemerintah melakukan pembelian Surat berharga serta melakukan operasi moneter. Pemerintah juga memberikan kredit mikro kepada pelaku usaha mikro, kecil dan menengah serta alokasi jaring pengaman bagi masyarakat miskin dalam bentuk tunai maupun sejenisnya (Economic Transition and Pathway to Progress Budget Speech 2020-21, 2020)

Langkah-langkah yang dilakukan pemerintah dalam bentuk bantuan tunai yang diperuntukkan bagi masyarakat menengah adalah upaya untuk membantu warga yang kehilangan pekerjaan dan bantuan sosial untuk mencukupi kebutuhan sehari-hari. Sehingga tidak mengherankan bila kemiskinan meningkat secara substansial selama krisis.

\section{Pemberlakukan Pembatasan Kegiatan Masyarakat}

Pembatasan Sosial diadaptasi sebagai strategi utama pencegahan dan untuk memperlambat penularan infeksi Covid-19 (Ferguson et al., 2020). Tidak tersedianya pengobatan membuat pemerintah harus memberlakukan Pembatasan Sosial Berskala Besar untuk mengurangi konsekuensi morbiditas dan fatalitas. Di Indonesia, penegakan pembatasan sosial yang ketat menjadi hal yang penting. Meskipun kebijakan ini menjadi dilema bagi sebagian besar orang yang bergantung 
pada ketersediaan pekerjaan sehari-hari. Dalam lingkungan seperti itu, pembatasan sosial menjadi gangguan bagi mereka yang menggantungkan pekerjaannya berdasarkan upah harian. Anggota masyarakat seperti buruh harian, pedagang, supir angkutan umum dipaksa untuk melakukan pembatasan sosial hanya untuk bertahan hidup (Search | Population Division, n.d.)

Pembatasan sosial juga mendapat tantangan di lingkungan ekonomi negara. Masyarakat menengah bawah harus mengantri untuk mendapatkan bantuan yang ditawarkan pemerintah, guna membeli kebutuhan pangan. Serta memanfaatkan transportasi berbiaya rendah dengan diskon yang ditawarkan oleh beberapa aplikasi transportasi online. Hambatan ekonomi ini dapat mempengaruhi kepatuhan pada norma pembatasan sosial. Situasi menjadi lebih rumit saat masyarakat bepergian di waktu liburan yang menyebabkan terjadinya kerumunan. Kepatuhan pada pembatasan sosial menjadi masalah karena kurangnya akses terhadap informasi seputar covid-19, serta kesadaran masyarakat akan keselamatan kesehatan. Faktor lain dalam kurangnya masyarakat dalam menjaga pembatasan sosial adalah kepercayaan atas validitas data dan fakta empiris.

\section{Diskusi}

Pemerintah Indonesia mengadaptasi banyak inisiatif untuk mencegah dan mengendalikan penyebaran Covid-19. Maka pemerintah mengembangkan "Satuan Tugas Covid-19". Di beberapa kota, Satgas Covid-19 melibatkan stakeholder dari pemerintah, Dunia Usaha, Masyarakat, dan Media Massa. (Majid et al., 2021) Tujuan utama dari pembentukan ini adalah untuk mencegah dan mengontrol penyebaran penyakit. Namun komitmen ini tidak bisa sepenuhnya dapat diaplikasikan apabila tidak ada kesadaran dan upaya dari masyarakat. Pemerintah Indonesia meningkatkan jumlah ICU, merekrut dan melatih dokter dan perawat, memberikan langkah-langkah keamanan bagi petugas kesehatan dengan melengkapi hazmat serta peralatan preventif tingkat tinggi lainnya.

Indonesia tertinggal dari rasio pasien dan dokter serta perawat dibandingkan dengan negara tetangga lainnya (COVID19 and Indonesia, n.d.) dan tidak memiliki fasilitas penanganan Covid-19 yang memadai. Orang di Indonesia yang berjuang pada taraf pemenuhan kebutuhan sandang pangan, pilihan utama selama periode pembatasan sosial adalah menghadapi dan mematikan virus agar perekonomian kembali normal sehingga pekerjaan akan lebih mudah diperoleh tanpa kebijakan pembatasan masyarakat.

Menghadapi dan mematikan virus dilakukan untuk mencegah kemungkinan terjadi keterpurukan ekonomi karena ketidakmampuan dalam mengakses pekerjaan untuk mendapatkan penghasilan. Hal untuk menghindari karantina wilayah yang dapat berakibat pada ketidakmampuan bekerja dan hilangnya pendapatan. Bantuan dari pemerintah sedikit terlambat dan butuh proses lama. Masyarakat yang berada di kelas menengah berubah status ekonominya menjadi menengah ke bawah, apalagi yang dalam kondisi normal masih membutuhkan upaya yang besar dalam memperoleh upah pekerjaan.

Praktik pembatasan sosial seringkali menjadi tantangan besar. Kurangnya kesadaran tentang Covid-19, pengetahuan yang kurang memadai menjadi faktor yang membuat Epidemi Covid-19 menjadi ancaman besar bagi bangsa. Pada saat yang sama, masalah seperti kemiskinan, kelaparan, dan ketakutan kehilangan pekerjaan menjadi masalah baru. 
Penggunaan masker dalam aktivitas di luar rumah merupakan hal penting dan efektif untuk membatasi penyebaran infeksi Covid-19 dimana 92\% orang di Indonesia memakai masker. Sekitar 75\% masyarakat patuh mencuci tangan dan menjaga jarak (COVID-19 and Indonesia, n.d.). Ini menunjukkan bahwa orang-orang di dalam daerah perkotaan mencoba beradaptasi dengan kebiasaan baru sesuai dengan pedoman untuk mencegah penyebaran penyakit. Oleh karena itu, merupakan tantangan bagi Pemerintah untuk mempengaruhi orang dan membuat mereka sadar tentang sifat virus yang menular. Tindakan tegas dapat diambil untuk memastikan kepatuhan jarak sosial dan pemakaian masker di tempat umum.

Pemerintah melalui Pemulihan Ekonomi Nasional menggalakkan program yang mendorong konsumsi masyarakat agar ekonomi terus berputar dan kesempatan kerja mulai terbuka kembali. Konsumsi rumah tangga menyumbang $57,6 \%$ dan menjadi permintaan tertinggi dalam konsumsi. Peringkat kedua disumbang oleh investasi sebesar 31,6\% (Moegiarso, 2021). Kuartal ke IV 2020 ekonomi mulai menampakkan indikator positif. Dimana beberapa usaha mulai berjalan dan impor bahan baku meningkat. Maka awal tahun ini menjadi tantangan bagi pemerintah untuk mendorong investasi. Sebab beberapa komoditas minyak kelapa sawit dan produk tambang di pasar asing memiliki harga bersaing.

Pemerintah meluncurkan paket kebijakan relaksasi Pajak Penjualan Atas Barang Mewah (PPnBM) guna mendorong industri otomatif sehingga kebijakan menurunkan harga kendaraan bermotor, dapat meningkatkan pembelian kendaraan bermotor. Dengan demikian, pada saat daya beli masyarakat mulai menggeliat, maka pertumbuhan akan permintaan barang mulai menunjukkan sinyal baik.

\section{Pembahasan}

Kebijakan pemerintah dalam menghadapi Pandemi Covid 19 memunculkan beberapa peluang usaha dan juga model bisnis untuk dapat tetap melangsungkan akivitas perekonomian. Meningkatnya aktivitas transaksi ekonomi secara online, meningkatkan utilititas dan juga pemakaian platform penjualan online. Salah satu contoh yang mendapat perhatian adalah dengan semakin meningkatnya aktivitas platform food delivery (Taufik \& Ayuningtyas, 2020). Munculnya beberapa platform baru yang mendukung aktivitas UKM juga menunjukkan tingkat penyesuaian dari pelaku ekonomi dan pembuat kebijakan dalam menghadapi pandemic covid -19.

Pelaku ekonomi menemukan keseimbangan, pola, cara beraktivitas baru ditengah pandemi covid 19. Hal ini menunjukkan bahwa tingkat adaptive yang cukup fleksibel pada pelaku ekonomi. Meskipun tidak sebagus sebelum terjadinya pandemic covid 19, namun hal ini memunculkan harapan ekonomi akan mencapai prosentase angka pertumbuhan dan keseimbangan baru di masa pandemic.

Semua sektor ekonomi terdampak, sehingga semua kalangan merasa terlibat, dan merasa perduli dengan pemulihan ekonomi di masa pandemic covid 19. Keperdulian dan keterlibatan ini sesuai dengan peran maupun kontribusi serta kemampuan yang dimiliki oleh setiap pelaku ekonomi. Ketegasan dan ketatnya pengawalan terhadap semua kebijakan ekonomi dimasa pandemic ini perlu diperhatikan. Masalah ekonomi akan bergulir menjadi masalah sosial budaya, bahkan bisa menjadi issue politik. Dan jika sudah menjalar ke hal hal lainnya seperti ini, akan semakin rumit penanganan pemulihan perekonomian di masa pandemi. 
Harapan masih muncul disaat pandemic covid -19. Dengan geliat aktivitas ekonomi di beberapa sektor ekonomi, maka kebijakan ekonomi seharusnya dapat semakin memberikan kesempatan dan stimulus untuk sektor sektor ini. Pemberian kesempatan keterlibatan industri dalam negeri untuk mensupport sektor kesehatan, sinergi antar lintas industri, juga perlu dimunculkan. Dengan tingkat konsumsi yang tinggi di negara ini, maka apabila dapat dioptimalkan dengan sinergi industri dalam negeri akan terproyeksikan pertumbuhan ekonomi yang sangat bagus. Peralatan kesehatan perlu diupayakan agar dapat dipenuhi dari dalam negeri sehingga menggeliakan perekonomian dengan terserapnya angkatan kerja, diperolehnya penghasilan dan meningkatkan konsumsi sehingga terjadi multiplier efek perekonomian pada sektor lain secara positif.

Komunikasi menjadi jembatan yang sangat diperlukan mulai penetepan, penerapan, pengendalian dan pengawasan serta evaluasi kebijakan ekonomi di masa pandemic covid 19. Data yang benar dan informasi yang valid akan mendukung kebijakan ekonomi yang sesuai dan dapat diaplikasikan (applicable). Kerjasama yang baik antara pelaku, pembuatdan pengawas pelaksanaaan perekonomian harus benar diperkuat. Pertaruhannya sangat besar dan mempengaruhi perekonomian nasional, apabila komunikasi tidak terjalin dengan baik sehingga perlu menciptakan iklim komunikasi deagan positif.

Pembuatan kebijakan harus lebih memperhatikan kebijakan ekonomi yang komperehensive, berlaku surut mengkoreksi beberapa periode fiskal sebelum pandemic covid 19 dan mendukung ekonomi baru dengan memberikan kesempatan keterlibatan industri dalam negeri untuk mensupport sektor kesehatan dan sinergi antar lintas industri. Pelaksanaan hendaknya didukung Ketegasan dan pengawasan yang ketat dengan komunikasi yang positif dan kondusif menjadi jembatan kerjasama yang baik antara pelaku ekonomi dan pembuat kebijakan ekonomi, serta para pengawas pelaksanaaan eknomi

\section{KESIMPULAN}

Pandemi Covid-19 membuat pelaku ekonomi mengalami kesulitan akibat hutang jatuh tempo yang memunculkan pengangguran baru pada sektor industry tertentu. Pada saat yang sama, pelaku ekonomi menemukan keseimbangan, pola dan cara beraktivitas baru yang menunjukkan tingkat adaptive yang cukup fleksibel. Muncul kepedulian dan keterlibatan sesuai dengan peran maupun kontribusi serta kemampuan yang dimiliki oleh setiap pelaku ekonomi. Namun kebijakan ekonomi yang telah diputuskan belum berpengaruh positif terhadap pemulihan perekonomian nasional akibatnya masih lemahnya komunikasi dalam penetepan, penerapan, pengendalian dan pengawasan serta evaluasi kebijakan ekonomi.

Pembuatan kebijakan harus lebih memperhatikan kebijakan ekonomi yang komperehensive, berlaku surut mengkoreksi beberapa periode fiskal sebelum pandemic covid 19 dan mendukung ekonomi baru dengan memberikan kesempatan keterlibatan industri dalam negeri untuk mensupport sektor kesehatan dan sinergi antar lintas industri. Pelaksanaan hendaknya didukung ketegasan dan pengawasan yang ketat dengan komunikasi yang positif dan kondusif menjadi jembatan kerjasama yang baik antara pelaku ekonomi dan pembuat kebijakan ekonomi, serta para pengawas pelaksanaaan eknomi. 
Penelitian selanjutnya hendaknya mengangkat permasalahan kebijakan ekonomi di masa pandemic covid 19 secara lebih mendalam. Penelitian lanjutan perlu lebih spesifik mencermati sektor yang masih belum optimal tersentuh kebijakan.

\section{DAFTAR PUSTAKA}

Badan Pusat Statistik. (n.d.). Retrieved February 16, 2021, from https://www.bps.go.id/pressrelease/2020/05/04/1714/jumlah-kunjungan-wismanke-indonesia-maret-2020-mencapai-470-90-ribu-kunjungan-.html

Badan Pusat Statistik. (2020). Agustus 2020: Tingkat Pengangguran Terbuka (TPT) sebesar 7,07 persen. BPS. https://www.bps.go.id/pressrelease/2020/11/05/1673/agustus-2020-tingkat-pengangguran-terbuka--tpt--sebesar-7-07-persen.html

COVID-19 and Indonesia. (n.d.). Retrieved February 1, 2021, from https://www.researchgate.net/publication/340645813_COVID19_and_Indonesia\%0A

Economic Transition and Pathway to Progress Budget Speech 2020-21. (2020).

Ferguson, N. M., Laydon, D., Nedjati-Gilani, G., Imai, N., Ainslie, K., Baguelin, M., \& Al., E. (2020). Impact of non-pharmaceutical interventions (NPIs) to reduce COVID-19 mortality and healthcare demand.

Ismal, R. (2020). Kuliah Umum: Strategi Kebijakan Moneter. Dalam Peecepatan Pemulihan Perekonomian Indonsia.

Kasus Covid-19 Pertama, Masyarakat Jangan Panik | Indonesia.go.id. (n.d.). Retrieved February 16, 2021, from https://indonesia.go.id/narasi/indonesia-dalam-angka/ekonomi/kasuscovid-19-pertama-masyarakat-jangan-panik

Majid, A. I., Muchin, S., \& Sunariyanto. (2021). NTERELATION INSTITUSIONAL COLLABORATION DALAM PENAGGULANGAN BENCANA COVID 19 DI K OTA MALANG (Study Pada Satgas Covid-19 Kota Malang). Respon Publik, 15, 64-69.

Moegiarso, S. (2021). Daya Ungkit Ekonomi Bangkit. FMB9ID_IKP.

Search | Population Division. (n.d.). Retrieved February 17, 2021, from https://www.un.org/development/desa/pd/search/node/indonesia

Statistik, B. P. (2020). Perkembangan Upah Pekerja/Buruh Januari 2021. Badan PUsat Statistik, No. $15 / 02 /$.

Sumarni, Y. (2020). Pandemi Covid-19: Tantangan Ekonomi dan Bisnis. Al-Intaj, 6.

Taufik, T., \& Ayuningtyas, E. A. (2020). DAMPAK PANDEMI COVID 19 TERHADAP BISNIS DAN EKSISTENSI PLATFORM ONLINE. Jurnal Pengembangan Wiraswasta, 22(01), 21. https://doi.org/10.33370/jpw.v22i01.389

WHO | World Health Organization. (n.d.). Retrieved February 17, 2021, from https://www.who.int/

Worldometer. (n.d.). Coronavirus Update (Live): COVID-19 Virus Pandemic. Retrieved February 16, 2021, from https://www.worldometers.info/coronavirus/ 